\title{
REFLEKSI GEKOKUJO DALAM TEKS DRAMA KYOUGEN BERJUDUL "BUAKU"
}

\author{
Eman Kusdiyana \\ Fakultas IImu Budaya, Universitas Sumatera Utara \\ Pos-el: eman_kusdiyana@yahoo.co.id
}

\begin{abstract}
A bstrak
Drama Kyougen berjudul Buaku menceritakan tentang konflik sosial antara golongan sosial atas (penguasa) dengan golongan sosial bawah (petani, buruh, tukang dan pedagang) yang terjadi di Jepang pada zaman M uromachi (1350-1573). Secara sosiologis yang ditekankan pada cerita Buaku ini adalah konflik sosial berupa perlawanan golongan sosial bawah terutama petani desa terhadap golongan sosial atas(Shugo D aimyo, D aikan) yang dikenal dengan istilah G ekokujo (bawahan melawan atasan). Dalam gerakan Gekokujo esensinya adalah rakyat bangkit, berpikir kritis, bersatu, dan menciptakan rasa kebersamaan diantara golongan sosial bawah khususnya petani desa untuk melawan para penguasa yang memeperlakukan golongan sosial bawah secara tidak manusiawi. Kajian ini mencoba untuk melihat sajauh mana cerita Buaku ini merefleksikan pertentangan antara golongan sosial bawah dengan golongan sosial atas yang diwujudkan dalam bentuk Gekokujo.Pendekatan yang digunakan adalah pendekatan sosiologis dengan metode deskriptif analitis dan hermeneutik. Pengumpulan data menggunakan metode studi kepustakaan dan terjemahanserta teknis analisis menggunakan metode wacana kritis. Hasil kajian dan pembahasan menunjukkan bahwa cerita Buaku ini sarat dengan pencerminan Gekokujo yaitu perlawanan golongan sosial bawah (petani, pelayan) terhadap golongan sosial atas (tuan atau majikan) pada zaman M uromachi.Golongan sosial bawah pada zaman M uromachi berada pada posisi masyarakat yang hidupnya mendapat tekanan dari penguasa, sehingga hidupnya penuh dengan penderitaan. Oleh sebab itu, golongan sosial bawah melakukan perlawanan terhadap penguasa yang dikenal dengan Gekokujo. Perlawanan yang dilakukan berdasarkan azas keadilan dan kemanusiaan yang mengedepankan bahwa manusia dalam kehidupannya harus adil, bijaksana serta menjunjung perikamunisaan.
\end{abstract}

Kata kunci: Kyougen, Buaku, konflik sosial, Gekokujo

\begin{abstract}
D rama of Kyougen entitled "Buaku" tells about a social conflict between thehigh-social class (authority) and the low-social class (peasants, laborers, craftsmen, and traders) happened in Japan in the era of Muromachi (1350-1573). Sociologically, Buaku tells about a social conflict, namely an opposition between thelow-social class, especially village peasants against the high-social class (Shugo Daimyo, Daikan) known as Gekokujo rebellion (superiors against inferiors). The essence of Gekokujo was that the people arose, critical, united to achieve the sense of togetherness among the low-social class especially viallage peasants against the highsocial class who treated them inhumanely. This study tries to find out to what extent Buaku reflects theconflict between the high-social classand the low-social class realized in Gekokujo. The approach used as the grand theory in the study was the sociological approach with the analytical-descriptive method and hermen eutic. $D$ ata were collected through the library studies and translation. The technique analysis used the critical discourse. Theresult shows that Buaku isfull of ther eflection of theopposition ofthelow-social class (peasants and employees) against thehigh-social class (masters or employers) in theera of M uromachi. Thelow-social class in the era M uromachi arein position of society that is under pressure on his life. So that his lifeis full of suffering. Therefore, thelow-social class figting against the ruler know as G ekokujo. Theresistance is based on theprinciple of justice and humanity. H uman beings must bejust and uphold humanity.
\end{abstract}

Keywords: Kyougen, Buaku, social conflict, Gekokujo 


\section{PENDAHULUAN}

Karya sastra pada dasarnya bukan mencatat mengenai kehidupan sehari-haritetapi menafsirkan realita kehidupan agar kehidupan tetap berharga dan lebih menghormati manusia sebagai makhluk ciptaan Tuhan yang Mahakuasa yang memiliki akal, perasaan dan budi pekerti (Sumardjo, 1994:8). Kehidupan seharihari dilihat oleh pengarang atau sastrawan dan diberi makna agar pembacanya kelak setelah membaca karya sastra dapat kembali menyadari kehidupannya dengan suasana dan pandangan yang baru. Dalam kehidupan sehari-hari manusiatidak lepas juga dari masalah yang harus dihadapi bahkan masalah yang dihadapi manusia selalu menimbulkan konflik. Dengan demikian, manusia pada prinsipnya ingin menyelesaikan masalah yang dihadapi sekalipun mereka akan menghadapi berbagai konflik yang ada seperti konflik dengan dirinya, dengan orang lain, dan dengan lingkungannya (Satari, 2003:58). Gambaran kehidupan manusia dalam karya sastra, tentunya dapat ditelaah dengan berbagai cara, misalnya bagaimana kehidupan manusia dengan berbagai konfliknya serta pemecahan masalahnya terefleksikan dalam karya sastra. Oleh karena itu, karya sastra dapat dimanfaatkan sebagai objek kajian untuk menganalisis makna kehidupan yang diungkapkan sastrawan. Dalam karya sastra drama, penggambaran kehidupan manusia,seperti adanya konflik dan benturanbenturan sosial, akan terasa lebih hidup, lebih bergerak, dan lebih dinamis. Dilihat dari alur yang baik dalam suatu karya sastra drama salah satunya harus ada unsur konflikasi (kegawatan). Dalam drama yang dikatakan baik senantiasa ada masalah yang dengan sendirinya akan melahirkan konflik. Teks atau naskah drama merupakan sal ah satu unsur yang harus ada dalam struktur drama yang merupakan bentuk cerita yang dipentaskan di atas panggung melalui gerakan-gerakan tubuh dan dialog. Isi drama pada umumnya adalah masalah kehidupan manusia yang lengkap dengan ber- bagai konflik dan berbagai aspek kehidupan yang dilihat pengarang secara jelas. Tidak sedikit karya sastra drama Jepang yang mengungkapkan masalah konflik sosial yang terjadi pada zamannya, salah satunya adalah drama Kyougen yang merupakan drama klasik Jepang. Menurut Isoji Asoo (1983:107-108) drama Kyougen merupakan drama komedi sebagai se lingan dalam pementasan drama $\mathrm{N}$ oh yang diperkirakan Iahirnya pada zaman M uromachi kira-kira tahun 1350. Dalam pementasannya, drama Kyougen memiliki tujuan untuk mengundang gelak-tawa para penonton, sehingga seringkali diselipkan sindiran-sindiran terhadap kontradiksi dalam masyarakat berupa lawakan-lawakan yang menggelitik. Dengan demikian, secara pendekatan sosiologis, drama Kyougen dapat mengungkapkan masalah sosial dan difungsikan sebagai suatu kritik sosial. Salah satu teks atau cerita drama K yougen yang mengungkapkan masalah kontradiksi dalam masyarakat pada zaman M uromachi berjudul Buaku. Drama Kyougen berjudul Buaku ini menceritakan hubungan antara golongan kelas atas sebagai penguasa dan golongan kelas bawah yang dikuasai yang dikenal dengan istilah Shujukankei (hubungan ala feodal Jepang). Cerita ini dapat merefleksikan konflik sosial yang terjadi pada zaman M uromachi. Konflik sosial terjadi diawali oleh pihak golongan atas yang bertikai dalam perebutan kekuasaan dan menimbulkan perang $\mathrm{N}$ anbokuchoran (perang kekaisaran utara dan selatan), perang 0 nin dan perang Sengoku Jidai. A kibat pertikaian ini menimbulkan penderitaan bagi golongan bawah terutama para petani desa. Pada saat yang sama para penguasa(D aimyo, D aikan) dalam menjalankan tugasnya dengan cara yang kejam tanpa mempedulikan kondisi masyarakat bawah yang hidup menderita. Masyarakat golongan bawah, terutama petani desa pada zaman M uromachi, sering mendapat perlakuan yang tidak manusiawi dari penguasa (Shugo Daimyo,Dikan), sehingga akumulasi dari penderitaan yang dirasakan oleh 
golongan bawah ini menimbulkan gejolak dari rakyat biasa untuk mencurahkan keluhankeluhannya melalui gerakan-gerakan yang menuntut keadilan dan diakui statusnya, diwujudkan dalam bentuk gerakan melawan terhadap para penguasa yang tamak dan zalim yang dikenal dengan istilah pemberontakan Gekokujo. Gekokujo merupakan suatu gerakan bawahan melawan terhadap atasan yang dalam hal ini pembantu melawan majikan atau tuannya (dan dimana-mana di seluruh wilayah Jepang pada zaman M uromachi terjadi pemberontakan Gekokujo seperti ini. Dalam gerakan Gekokujo ini esensinya adalah rakyat bangkit, berpikir kritis, bersatu, dan menciptakan rasa kebersamaan diantara gol ongan sosial bawah untuk melawan penguasa yang dalam menjalankan tugasnya tidak mempedulikan kehidupan rakyat biasa. Pada cerita Buaku ini unsur perlawanan dari golongan sosial bawah terhadap golongan sosial atas (Gekokujo) yang ditunjukkan dengan rakyat mulai bersatu, berpikir kritis, dan rasa kebersamaan antar golongan sosial bawah paling ditekankan. Demi melangsungkan daya hidup golongan sosial bawah pada zaman M uromachi hanya dengan cara bersatu padu dan menciptakan rasa kebersamaan untuk melawan golongan atas yang berkuasa (D aimyo, D aikan). Kajian cerita Buaku ini bertujuan untuk mendeskripsikan konflik sosial berupa perlawanan golongan sosial bawah, yaitu petani, pelayan/ pembantu, terhadap golongan sosial atas, yaitu Daimyo, tuan/ majikan, sebagai ekses dari adanya para penguasa (Shugo Daimyo 'tuan feodal') yang sewenang-wenang memperlakukan rakyat biasa pada zaman M uromachi. Diharapkan hasil kajian ini dapat memberikan kontribusinya dalam membangun konsep teoretis pengkajian sastra asing (Jepang) dan juga berguna bagi kita untuk melihat bagaimana masyarakat biasa dalam menyelesaikan masalah sosial secara demokratis kaitannya dengan dominasi dan kesewenang-wenangan pihak penguasa dalam menjalankan tugasnya. Dari kajian ini pula dapat diambil hikmahnya, bahwa hanya dengan rasa kebersamaan, bersatu padu, dan berpikir kritis kita sebagai masyarakat bawah dapat melawan suatu ketamakan, kesewenangwenangan, kezaliman, dan ketidakadilan yang dilakukan pihak penguasa.

\section{TEORI DAN METODE}

Dalam melakukan suatu kajian terhadap karya sastra seyogyanya berangkat dari pola pikir tertentu yang dirumuskan dalam kerangka perumusan dasar-dasar teoritis penelitian. Berdasarkan pemikiran tersebut, dalam mengkaji karya sastra diperlukan sudut pandang keilmuan tertentu seperti: dari sudut pandang ilmu sejarah, sosiologi, psikologi, dan Iain-lain. Cara memandang dan mendekati suatu objek disebut dengan istilah pendekatan. Pendekatan adalah asumsi-asumsi dasar yang dijadikan pegangan dalam memandang suatu objek. Untuk membahas tentang Gekokujo yang diungkapkan dalam drama K yougen yang berjudul Buaku ini, penulis menggunakan pendekatan sosiologis dan metode deskriptif analitis serta hermeneutik. Teknik pengumpulan data menggunakan metode studi kepustakaan dan penerjemahan. Teknik analisis menggunakan metode wacana kritis. Langkahlangkah untuk melakukan analisis dan pembahasan adalah pertama, penulis menjelaskan pendekatan sosiologis dalam kajian sastra menurut Atar Semi, metode hermeneutik me nurut Paul Recouer, metode wacana kritis menurut Teun Van Dijk, Kemudian mengaplikasikan teori dan metode dalam analisis teks cerita Buaku dengan cara menafsirkan atau memberi makna pada pesan yang terkandung dalam teks untuk menggambarkan gejala sosial atau konflik sosial yang terjadi pada zaman Muromachi. Selanjutnya dilakukan pembahasan dan pengambilan kesimpulan.

Menurut A tar Semi (1993:73) pendekatan sosiologis bertolak dari asumsi bahwa sastra merupakan pencerminan kehidupan masyarakat. Melalui karya sastra seorang pengarang 
mengungkapkan problem kehidupan yang pengarang itu sendiri ikut berada di dalamnya. Pendekatan sosiologis dalam sejarah awal kemunculannya memandang sastra sebagai cermin sejarah, terutama sejarah pertentangan kelas. Segala jenis aktivitas kehidupan masyarakat, seperti budaya, ekonomi, industri, memberi semangat dan pengaruh besar kepada pe nulis. Semakin banyak gejolak sosial dan dialektika yang terjadi di tengah masyarakat semakin kaya sastrawan dengan ide dan gagasan. Para sastrawan bertanggung jawab merekam gejolak sosial tersebut melalui karya sastra yang ditulisnya. Dalam konsepsi pendekatan sosiologis, analisis intrinsik lebih menitikberatkan kepada analisis perwatakan tokoh utama cerita. Tokoh yang dinilai tinggi adalah tokoh yang dibentuk oleh masyarakat dan lahir dari gejolak masyarakat. Perwatakan yang dikembangkan penulis hendaknya perwatakan ideal yang sesuai dengan norma tingkah laku yang berkembang di dalam masyarakat dan tokoh tersebut dengan gagah berani tampil ke depan memperjuangkan kepentingan masyarakat kelas bawah menghadapi penguasa dan kaum borjuis. Selain itu, dalam konsepsi pendekatan sosiologis, karya sastra merupakan medium yang paling efektif untuk menggerakan masyarakat berjuang memenangkan kepentingannya terhadap kesewenang-wenangan kaum minoritas dan kaum penguasa. Berdasarkan pendekatan sosiologis di atas, penulis mengkaji atau melihat bagaimana konflik social atau pertentangan kelas sosial yang terjadi pada zaman M uromachi antara golongan sosial bawah (petani, tukang, pelayan) dengan golongan sosial atas sebagai penguasa (D aimyo, Daikan) yang diwujudkan dalam bentuk pemberontakan Gekokujo yang diungkapkan oleh sastrawan drama Z eami dalam cerita Buaku. Dalam pembahasannya akan lebih difokuskan kepada perwatakan tokoh yang lahir dari gejolak masyarakat dan sesuai norma tingkah laku yang berkembang di masyarakat pada zaman M uromachi. Tokoh utama dalam cerita Buaku, yang merepresentasikan golongan masyarakat untuk memperjuangkan kepentingan masyarakat bawah pada zaman M uromachi, adalah Buaku itu sendiri. Dari interaksi para tokoh cerita antara Buaku, Tuan, majikan, dan Tarokaja (pelayan) dapat dilihat masalah sosial, konflik sosial, atau protes sosial yang terjadi pada zaman yang bersangkutan. Langkah kerja untuk menemukan dan menunjukkan adanya pertentangan atau perlawanan golongan sosial bawah terhadap golongan sosial atas (Gekokujo) yang diungkapkan oleh sastrawan Zeami dalam cerita Buaku di atas, tentunya penulis menganalisis teks cerita Buaku dan mengambil cuplikancuplikan yang mengindeksikalkan adanya perlawanan golongan sosial bawah terhadap golongan atas yang dalam hal ini di representasikan oleh tokoh utama, Buaku, sebagai pekerja atau pembantu tuan/ majikan yang dianggap pemal as atau tidak setia kepada tuannya. Kemudian akan menunjukkan juga rasa kebersamaan, persatuan dan berpikir kritis dari golongan sosial bawah sebagai dasar kekuatan untuk melakukan Gekokujo. Cerita Buaku, berdasarkan konsepsi pendekatan sosiologis, bisa dijadikan medium yang efektif untuk menggerakan masyarakat berjuang memenangkan kepentingannya terhadap kesewenangwenangan kaum minoritas atau kaum penguasa pada zaman M uromachi. Dalam pengumpulan data, penulis menggunakan metode studi kepustakaan yaitu teknik pengumpulan data dengan mengadakan studi penelahaan terhadap teks-teks, literatur-literatur, catatancatatan, dan laporan-laporan yang ada hubungannya dengan masalah yang dipecahkan (Nazir, 1998:111). Kemudian metode penerjemahan yaitu suatu metode yang digunakan untuk menerjemahkan bahasa asing (bahasa Jepang\} ke dalam bahasa Indonesia. Metode penerjemahan yang digunakan adalah penerjemahan komunikatif (communicative translation) menurut Newmark (1988:47), menurutnya penerjemahan komunikatif berupaya 
untuk menerjemahkan makna kontekstual dariteks Bahasa Sumber (Bsu), baik aspek kebahasaan maupun aspek isinya agar dapat diterima dan dimengerti oleh pembaca. Untuk teknik analisis data, penulis menggunakan wacana kritis dan hermeneutik, wacana kritis menurut Teun Van Djik dalam Maqdum (2011) yaitu suatu metode untuk menggali isi, pesan-pesan, yang terungkap pada objek pembahasan dan memberi makna pada pesan yang terkandung didalam teks untuk menggambarkan gejala sosial atau konflik sosial yang terjadi. Dalam melihat suatu teks Van Djik membagi dalam tiga tingkatan. Pertama, struktur makro. Makna global dari suatu teks yang dapat diamati dari topik/ tema yang diangkat oleh suatu teks. Kedua, Superstruktur. Kerangka suatu teks, seperti bagian pendahuluan, isi, penutup. Ketiga struktur Mikro. Makna lokal dari suatu teks yang dapat diamati dari pilihan kata, kalimat dan gaya yang dipakai oleh suatu teks. Datanya berupa kata-kata, kalimat, dan wacana yang mengandung pertentangan atau perlawanan golongan sosial bawah terhadap golongan sosial atas pada zaman M uromachi. Sumber datanya adalah drama Kyougen yang berjudul Buaku karya Zeami. Metode hermeneutik menurut Paul Ricoeur dalam Mega (2013) adalah suatu metode untuk memahami teks yang pada akhirnya ujung dari proses itu adalah ditemukannya makna atau pesan. Paul Ricoeur mendefinisikan hermeneutika yang mengacu pada fokus eksegesis tekstual sebagai elemen distingtif dan sentral dalam hermeneutika. Maksudnya hermeneutika merupakan teori tentang kaidah-kaidah yang menata sebuah eksegesis, dengan kata lain sebuah interpretasi teks partikular atau kumpulan potensi tanda-tanda keberadaan yang dipandang sebagai sebuah teks.Dengan demikian, hermeneutika adalah proses penguraian yang beranjak dari isi dan makna yang nampak ke arah makna terpendam dan tersembunyi.

Berdasarkan teori dan metodeyang di telah di jelaskan di atas, penulis menganalisis cerita
Buaku dengan cara menfasi rkan atau memberi makna teks cerita Buaku yang di dalamnya terdiri dari tanda-tanda yang memberikan makna pada pesan yang terkandung dalam teks untuk menggambarkan gejala sosial, konflik sosial yang terjadi pada zaman M uromachi yang diungkapkan pengarang Zeami.

\section{HASIL DAN PEMBAHASAN}

Berdasarkan latar belakang sejarah, drama Kyougen lahir pada zaman Chusei, tepatnya pada zaman M uromach iantara tahun 13501450, dan merupakan drama yang dapat dinikmati oleh seluruh Iapisan masyarakat Jepang (Inoura, 1971:11-13). Masyarakat pada zaman Chusei awal sebetulnya menuju masyarakat feodal. Masyarakat feodal adalah masyarakat yang didominasi oleh pemerintahan militer yang hidup di atas tanah yang terpecah-belah. Inti sistim feodal adalah muatan dua hubungan pribadi yaitu antara raja dengan tuan-tuan tanah dan antara tuantuan tanah dengan petani. Oleh karena itu, dapat dikatakan ciri utama dari sistem feodal adalah adanya penyerahan diri seseorang ketangan orang lain sekedar untuk memperoleh perlindungan dan pemeliharaan. Hubungan tersebut berupa hubungan tuan dengan petani sebagai hamba (Martin, 1990:165-166). Kemudian hubungan tuan dan petani sebagai hamba dapat dikatakan hubungan feodal ala Jepang yang dikenal dengan istilah Shujukankei. Hubungan seperti ini ternyata besar sekali pengaruhnya terhadap kehidupan masyarakat kala itu. Masyarakat feodal bermula dari berkuasanya kaum militer (Samurai) di bawah pimpinan Minamoto no Yoritomo yang diangkat sebagai Shogun (Jenderal) pada zaman Kamakura (1192-1333), kemudian dilanjutkan dengan pemerintahan A shikaga Takauji pada zaman M uromachi (1333-1573), Oda N obunaga dan Toyotomi Hideyoshi pada zaman A zuchi M omoyama (1573-1600), dan diakhiri oleh pemerintahan Tokugawa leyasu pada zaman Edo (1600-1868). Dari keempat pemerintahan 
feodal tersebut, pemerintahan pada zaman M uromachi-lah yang paling banyak terjadi huru-hara dan pemberontakan yang sifatnya meluas ke seluruh provinsi. Salah satunya adalah pemberontakan Gekokujo. Pemberontakan ini pada dasarnya timbul diakibatkan oleh para penguasa yang dalam menjalankan tugasnya tanpa menghiraukan penderitaan rakya jelata (Sakamoto, 1981). Keadaan yang kacau ini dijadikan kesempatan oleh para penguasa provinsi (Shugo Daimyo) untuk meluaskan daerahnya sehingga penguasa provinsi tersebut menjadi kuat dan menguasai tanah yang luas. Dengan kekuatan dan kekuasaan yang mereka miliki, para penguasa menjalankan tugasnya dengan cara yang kejam tanpa memedulikan kondisi masyarakat yang dikuasainya. Sebagai bukti sejarah bahwa penguasa provinsi (Shugo D aimyo) dan bahkan penguasa pemerintah kuil ( $D$ aikan)yang bertindak sewenang-wenang dan kejam terhadap masyarakat bawahadalah seperti berikut. Yokoi Kiyoshi (1993:183-198) mengatakan para petani M agojiro pada tanggal 27 November 1334 berangkat ke suatu tempat yang disebut 0 niyu. Saat itu adalah hari pasar, mereka berangkat untuk berdagang. Di pasar, tentu penuh dengan para saudagar yang datang untuk berniaga. Di dalam kerumunan orang di pasar, tiba-tiba para saudagar itu diserbu oleh sejumlah orang. Mereka merampas uang, barang milikorang-orang yang ada di tempat itu, tetapi akhirnya para perampas tersebut dapat ditangkap. Orang-orang yang kebetulan ada disitu hanya termenungdan terkejut melihat kejadian itu. Ternyata orang-orang yang merampas adalah Tohoku Shugo D aimyo(Shugo $D$ aimyo daerah Tohoku) yaitu bernama Hinoshin Bei, orang tersebut diutus oleh Shugo Daimyo untuk merampas barang-barang milik orang. A da juga gerakan orang jahat yang dicela oleh pihak tuan tanah pemerintahan kuil (Toji). Mereka pada 21 November 1334 malam hari menyerbu rumah petani yang merupakan gudang pihak tuan tanah feodal.Mereka merampas berbagai macam barang, bahanbahan, dan juga beras upeti yang disimpan. Ternyata dalam aksinya mereka dibantu oleh Shugo D aimyo. Sebagai bukti bahwa petani dan tukang kuli pada zaman tersebut menderita tertulis dalam Toji H yakugo M onjo (arsip atau dokumen pemerintah kuil). Isinya adalah Waki Bukuro(seorang Daikan) menyuruh petanipetani sebanyak 600 orang untuk menanami sawah dan ladang miliknya. Hal ini mengakibatkan petani terlambat dalam menggarap tanahnya sendiri, sehingga mereka tidak bisa panen. Setiap hari petani disuruh ke tempat Waki Bukuro, kira-kira jaraknya 20 kilometer pulang pergi. Tukang-tukang kuli dari bulan Maret sampai bulan A gustus 1334 disuruh kerja di Kyoto.Hal ini belum pernah terjadi sebelumnya. Kemudian, untuk membuat benteng, Waki Bukuro memungut beras dari petani untuk keperluan konsumsi para pekerja yang sedang membuat benteng. Petani setiap hari disuruh bekerja. Selanjutnya Waki Bukuro merencanakan untuk menyel ewengkan sawah milik Tokijawa Myo dan merusak rumahrumah petani dan reruntuhannya diambil untuk membuat benteng. Melihat latar belakang sejarah di atas, kelihatannya golongan sosial bawah, seperti petani, tukang, bahkan pedagang, mendapat perlakuan yang tidak berperikemanusiaan dari pihak penguasa yaitu Shugo Daimyo dan Daikan, seperti merampas, memperkerjakan petani dan tukang secara paksa, sehingga mengakibatkan para petani dan tukang hidupnya menderita. Akibatnya timbul antipati para petani, tukang, dan masyarakat bawah lainnya terhadap penguasa dan akhirnya keluhan-keluhan penderitaan yang masyarakat bawah rasakan terakumulasi sehingga menimbulkan gerakan-gerakan untuk melawan pihak golongan atas yang berkuasa yang dikenal dengan istilah Gekokujo. Kondisi sosial seperti di atas, dijadikan seting cerita drama Kyougen oleh Zeami dalam salah satu judulnya yaitu Buaku. Untuk membahas sejauhmana kondisi sosial yang terungkap 
dalam drama Kyougen berjudul Buaku di atas, dapat dilihat dari analisis setiap unsur yang membentuk struktur drama.Menurut Jakob Sumardjo (1994:139-148) ada lima unsur dasar dalam struktur ceritadrama yakni plot, tokoh cerita/ karakter, bahasa,buah pikiran atau tema, dan motivasi. Pada kajian ini, penulis hanya akan membahas beberapa unsur yang terdapat dalam struktur cerita drama yang berkaitan langsung dengan pembatasan objek yang akan dibahas. Unsur-unsur tersebut adalah seperti berikut.

\section{Buah Pikiran atau Tema}

Pada dasarnya dalam setiap naskah drama terdapat ide-ide atau gagasan-gagasan yang ingin diungkapkan pengarang, yang disebut dengan pikiran. Meskipun gagasan yang ingin diungkapkan itu sifatnya sangat sederhana tetapi selama gagasan tersebut menggambarkan manusia dalam laku dan diungkapkan melalui bahasa dalam bentuk dialog, maka drama tersebut senantiasa erat kaitannya dengan pikiran. Gagasan atau pikiran yang dituangkan ke dalam bentuk naskah drama sering juga disebut tema. Setiap lakon tertentu yang akan dipentaskan pasti memiliki tema. Untuk melihat tema dari cerita Buaku ini, berdasarkan uraian di atas, penulis dapat me ngambil kesimpulan, pertama adalah konflik sosial yang timbul antara golongan sosial bawahs (petani, pekerja, pelayan) dengan golongan sosial atas (tuan feodal, D aimyo) yang berkuasa pada zaman M uromachi. Kedua adalah gerakan golongan sosial bawah melawan golongan atas merupakan salah satu solusi menyelesaikan masalah ketidakadilan dan tindakan sewenang-wenang pihak penguasa. Ketiga adalah bersatu,berpikir kritis dan rasa kebersamaan dari golongan sosial bawah sebagai landasan yang kuat timbulnya pemberontakan Gekokujo. Tema utama dari cerita Buaku adalah persatuan, berpikir kritis dan rasa kebersamaan yang diwujudkan golongan sosial bawah pada zaman Muromachi sebagai landasan yang kuat untuk melawan penguasa yang tidak adil dan tidak berperikemanusiaan.

\section{Tokoh Cerita/Karakter}

Tokoh cerita merupakan unsur utama yang mendorong dan menghidupkan lakon. Dikatakan demikian karena tokoh cerita adalah orang yang mengambil bagian dan mengalami peristiwa-peristiwa atau sebagian dari peristiwaperistiwa yang digambarkan di dalam plot (Sumardjo, 1994:144). Jika dilihat dari sifat dan kedudukannya tokoh cerita dal am karya sastra drama beraneka ragam. Ada tokoh yang bersifat penting yang digolongkan kepada tokoh utama (mayor) dan ada pula tokoh yang tidak terlalu penting yang digolongkan kepada tokoh pembantu (minor). Berdasarkan kedudukannya, tokoh cerita ada yang berkedudukan sebagai tokoh protagonis, yaitu tokoh yang pertama-tama berprakarsa dan berperan sebagai penggerak ceritera. Tokoh protagonis ini adalah tokoh yang pertama-tama menghadapi masalah dan terlibat dal am kesul itan-kesulitan, bahkan pembaca atau penonton biasanya berempati kepadanya. Kemudian, Iawan dari protagonis adalah antagonis yang berperan sebagai penghalang dan membuat masalah bagi protagonis. Tokoh utama atau pemeran utama dalam drama Kyougen biasa dikenal dengan istilah Shite Kata, sedangkan tokoh pembantu dikenal dengan istilah Tsure Kata atau Koado. Yang menjadi tokoh utama dari drama Kyougen yang berjudul Buaku ini adalah Buaku itu sendiri. Tokoh buaku ini adalah tokoh cerita yang mendapat perlakuan yang tidak manusiawi dari tuan atau majikannya karena kemalasan dan ketidaksetiaan Buaku terhadap tuannya. Selanjutnya situasi ini menjadi sumber konflik antara Buaku dan tuannya. Tokoh Buaku menjadi sentral dalam peristiwa-peristiwa pertama sampai akhir, Tokoh pembantu adalah tuan/ majikan dan Tarokaja yang kalau dilihat dari pemunculannya maupun dalam ketelibatannnya pada peristiwa-peristiwa dalam drama tersebut tidak begitu penting. 
Jadi, sifatnya tokoh tuan dan Tarokaja ini hanya memancing pembicaraan atau dialog saja. Tokoh berikutnya adalah tuan/ majikan, tokoh ini menjadi sasaran perlawanan dari tokoh utama yang berkedudukan sebagai peran kelas sosial bawah yang menderita, dan hal ini yang menimbulkan konflik. Sedangkan tokoh lain seperti Tarokaja sebagai peran pembantu, dalam cerita Buaku ini berperan menjadi penengah atau mediator yang pada akhirnya mendukung atau membela tokoh Buaku yang sama-sama statusnya golongan sosial bawah. Tokoh Tarokaja ini, bisa dikatakan tokoh yang cerdik dalam memperdaya golongan atas (tuan/ majikan), yang sekaligus mempresentasikan golongan sosial bawah yang cerdik, berpikir kritis, dan tidak bisa dianggap sepele oleh golongan atas, yang menciptakan rasa persatuan dan kebersamaan sesama masyarakat bawah.Pembahasan tokoh cerita Buaku secara detailnya akan penulis paparkan pada cuplikan-cuplikan berikut.

\section{Cuplikan 1:}

“...Buaku no Bumatsu ni kaninbukuro no sho o kirashita nushi, seibej shitekuruyou Tarokaja ni meijimasu. Hisshi ni kabaidateshita Tarokaja mo nushi no kemaku niwa katezu, tsui ni Buaku no sebai ni dekakemasu... " (M atsuda, 1976 )

Terjemahan:

“.. Tuan yang tak tahan menahan kesabaran terhadap ketidaksetiaan atau kemalasan Buaku (pekerjanya), menyuruh Tarokaja (pelayan tuan) supaya membunuh Buaku. Walaupun Tarokaja membela Buaku, tapi kemarahan tuannya tidak terbendung, akhirnya Tarokaja berangkat untuk membunuh Buaku.."

“Tuan yang tak tahan menahan kesabaran" menunjukkan bahwa karakter atau watak tuan (penguasa) adalah tidak sabaran. Kemudian "kemarahan tuannya tidak terbendung" menunjukkan watak tuan yang pe- marah dan kejam. Watak tuan atau majikan seperti ini, kenyataannya pada zaman M uromachi terjadi, sesuai dengan watak penguasa, dalam hal ini penguasa provinsi (Shugo Daimyo) yang selalu mengondisikan bawahan pekerjanya secara keras dan kasar. Bahkan jika bawahan atau pekerjanya tidak setia kepadanya, tuan akan marah besar dan hukumannya dibunuh. Disisi lain dari cuplikan di atas terlihat Tarokaja membela Buaku, hal ini menunjukkan bahwa Tarokaja (pelayan tuan) berwatak toleran sesama teman yang sesama status golongan sosial bawah. Namun, Tarokaja memiliki pikiran yang dilematis, di satu sisi harus membantu atau membela Buaku yang harus dibunuh tapi disatu sisi lagi Tarokaja harus setia terhadap majikan. Kesetiaan terhadap majikan ini merupakan perwujudan dari Shujukankei (hubungan feodal ala Jepang). Bahkan kesetiaan bawahan terhadap tuan ini bisa tanpa batas sampai pada akhirnya bisa bunuh diri demi tuannya. Kesetiaan seperti ini mungkin tidak akan terjadi di Indonesia. Dengan demikian, watak dari Tarokaja selain toleran juga setia. Cuplikan di atas bisa dikatakan sebagai sumber konflik antara golongan atas sebagai tuan/ majikan dengan golongan sosial bawah sebagai pekerja maupun pelayan yang diperankan oleh tokoh Buaku dan Tarokaja.

Cuplikan 2 :

"... Y orokonde mukaeta Buaku ni, kyou no kyaku no chisou toshite kawau o o jisan sureba, nushi no kigen mo naorou to chie o tsuke, chikaku no ike ni annai sasemasu. Soko de ike ni hairi, kawauo o ou Buaku no geki o tsuite utoshita Tarokaja mo, oshimondo no sue no shuushouna Buaku no sugata o mite kesshin ni buri..."

Terjemahan :

“...Tarokaja mengatakan kepada Buaku apabila membawa ikan sebagai jamuan makan malam tamu tuan, suasana hati tuanpun akan menjadi baik dan akan memberikan ampunan, Ialu Tarokaja menunjukkan kolam 
dekat rumahnya dan menyuruh Buaku turun ke kolam tersebut, Tarokaja walaupun bermaksud membunuh Buaku dengan mengambil kesempatan Buaku yang dalam keadaan mengejar ikan di kolam seperti yang telah direncanakan...."

Dari cuplikan di atas, telihat bahwa Buaku turun ke kolam atas perintah Tarokaja, dia menuruti apa yang diperintahkan oleh Tarokaja. Ini menunjukkan bahwa watak Buaku adalah polos, penurut, dan penyabar. Polos, penurut, dan penyabar yang direpresentasikan oleh Buaku memang merupakan tabiat dari masyarakat golongan bawah yang kala itu mendapat tekanan dari pihak penguasa terutama Shugo Daimyo dan Daikan. Tekanan tersebut berupa perampasan, pemaksaan dan kekejaman. Pada awalnya masyarakat golongan bawah tersebut pasrah, penurut, sabar, dan menerima saja terhadap tindakan atau perilaku penguasa. Oleh karena itu, pekerja atau pelayan yang sekali saja melawan atau tidak setia terhadap tuannya, maka tuannya tidak segan-segan dan de ngan arogan menyiksa bahkan membunuhnya.

\section{Cuplikan 3 :}

“...Ichiou nanushi no fushin o uchitoshita Tarokaja ga, ikkei o anjite Buaku o yurei ni shitate, tekitou ni dori tukurotteiru aida ni Buaku wa hashigakari kara kie yurei rashii sugata ni natte saitojoushimasu..."

Terjemahan :

“.....Tuan terkejut melihat Buaku, Tarokaja untuk sementara menghapus kecurigaan tuannya, membuat suatu rencana, yakni membuat Buaku menjadi yurei (hantu). Selama ngomongngomong (untuk tujuan supaya Buaku sembunyi) Buaku hilang dari Hashigakari (jembatan yang melintang di panggung), kemudian berubah menjadi hantu, lalu muncul kembali..."

Dari cuplikan di atas, terlihat bahwa Tarokaja dan Buaku membuat rencana untuk menghilangkan kecurigaan tuannya, caranya menipu tuannya dengan pura-pura Buaku menjadi yurei (hantu). Tipuan yang dilakukan Tarokaja dan Buaku adalah suatu tipuan yang dilakukan dengan tujuan menginsafkan tuan dari tindakannya yang sewenang-wenang, dari ketamakan dan kekejaman yang tuan lakukan dalam kehidupan sehari-harinya. Dengan demikian, Tarokaja dan Buaku yang tergolong masyarakat golongan bawah memiliki watak yang cerdik. Sehingga dengan kecerdikannya bisa mengalahkan kecerdikan golongan sosial atas (penguasa). Dengan demikian cuplikan di atas menunjukkan adanya kecerdikan golongan sosial bawah yang bisa memperdaya goIongan sosial atas dan ini merupakan indeksikal adanya perlawanan golongan sosial bawah terhadap golongan sosial atas (Gekokujo).

\section{M otivasi}

Motivasi atau dorongan merupakan unsur yang menentukan, baik terhadap perbuatan maupun terhadap percakapan (dialog) yang diucapkan oleh tokoh cerita, khususnya tokoh utama atau tokoh protagonist. .Motivasi ini kedudukannya yang khas dan menonjol dalam karya sastra drama dan sangat membantu usaha penelaahan karya-karya sastra drama kalau dipahami. Berdasarkan konsep motovasi yang telah diuraikan di atas, penulis mencoba menentukan motivasi dari cerita Buaku ini, yaitu perlakuan golongan sosial atas terhadap golongan sosial bawah yang sewenang-wenang, kejam dan tidak manusiawi yang mengakibatkan timbulnya gerakan golongan sosial bawah melawan terhadap golongan atas (penguasa) yang dikenal dengan istilah Gekokujo.Semua perkataan dan perbuatan tiga tokoh cerita Buaku tersebut bertolak dari motivasi tersebut. Sehingga, untuk membahas sejauhmana pengungkapan Gekokujo dalam cerita Buaku ini dengan melihat buah pikiran/ tema, tokoh cerita/ karakter, dan motivasi, yang telah dijelaskan di atas, penulis akan memaparkannya dalam analisis teks cerita Buaku dibawah ini berdasarkan pendekatan sosiologis. Kemudian 
penganalisisan dilakukan dengan mengambil cuplikan-cuplikan yang mengindeksikalkan Gekokujo, yaitu perlawanan golongan sosial bawah-yang dalam hal ini direpresentasikan oleh tokoh Buaku (pekerja) dan Tarokaja (pelayan sekaligus sebagai badut) --terhadap golongan sosial atas- yang direprentasikan oleh tokoh tuan atau majikan.

\section{Analisis sosiologis teks cerita Buaku}

Teks cerita Buaku yang penulis gunakan merupakan garis besar teks yang telah diterjemahkan penulis kedalam bahasa Indonesia dari teks aslinya yang ditulis oleh Tamotsu Matsuda (1976).

\section{Cuplikan 1:}

“...Buaku no Bumatsu ni kaninbukuro no sho o kirashita nushi, seibei shitekuruyou Tarokaja ni meijimasu..." (M atsuda, 1976)

Terjemahan:

“...Tuan yang tak tahan menahan kesabarannya terhadap ketidaksetiaan atau kemalasan Buaku (pekerjanya), menyuruh Tarokaja (pelayan) supaya membunuh Buaku..."

\section{Analisis :}

Dari cuplikan di atas, terlihat adanya ke tidaksetiaan atau kemalasan tokoh Buakuyang merupakan indeksikal dari pertentangan terhadap tuan atau majikannya. Ketidaksetiaan dan kemalasan yang dilakukan oleh bawahan, baik itu sebagai pekerja, pelayan, atau pun se bagai hamba, tidak boleh terjadi dalam masyarakat feodal Jepang. Tetapi kenapa hal ini terjadi? Sesuai dengan konteks sejarahnya, kenyataan pada zaman Muromachi, tindakan penguasa Shugo D aimyo keluar dari tugas yang diberikan oleh Shogun (jendral/ pimpinan militer), sebagai pejabat yang bertugas menertibkan dan mengamankan wilayah kekuasaannya. Namun pada kenyataannya Shugo D aimyo bukannya menertibkan atau mengamankan wilayah dari kekacauan atau kejahatan, malah membuat onar bahkan merampas barang-barang milik masyarakat dan juga membantu aksi dari para bajingan yang merampok gudang petani. Selain itu, Daikan yang merupakan penguasa kuil juga turut berbuat sewenang-wenang terhadap para petani dan tukang. Para petani dan tukang dipaksa untuk mengerjakan tanah milik Daikan, sehingga petani gagal panen. Para tukang juga disuruh secara paksa mengerjakan pembuatan benteng yang biayanya dari pungutan beras dari petani. Bahkan tidak sedikit rumah petani dibakar, kemudian kayunya dijadikan untuk pembuatan benteng. Akibatnya semua petani dan tukang hidup menderita. Akhirnya penderitaan ini terakumulasi dan menimbulkan suatu gerakan dari para petani dan tukang, yakni bawahan melawan atasan (Gekokujo). Perlawanan golongan sosial bawah ini diaplikasikan salah satunya dalam bentuk pembangkangan, kemalasan, dan ketidaksetiaan terhadap tuan. Dengan demikian, ketidaksetiaan dan kemalasan yang dilakukan tokoh Buakuini merupakan indeksikal dari perlawanan golongan sosial bawah terhadap golongan sosial atas (Gekokujo). Kemudian dari cuplikan “... tuan menyuruh Tarokaja supaya membunuh Buaku..." menunjukkan bahwa golongan sosial atas (tuan) sebagai golongan masyarakat yang berkuasa dan dengan kekuasaan serta kekuatannya dapat sewenang-wenang menindas golongan sosial bawah yang lemah secara kejam. Hal ini merupakan indeksikal atau simbol dari kekejaman dan arogansi dari pihak penguasa.

\section{Cuplikan 2:}

“...H isshi ni kabaidateshita Tarokaja mo nanushi no kenmaku niwa katezu, tsuini Buaku No seibai ni dekakemasuga, budo 0 kokoroeta Buaku no koto, uchisonjite nanushi no meyou o kitsukeru yori damashiuchi ni shiyou to kesshinshimasu...." (M atsuda, 1976)

Terjemahan:

“...Walaupun Tarokaja membela Buaku, tapi kemarahan tuan tidak 
terbendung, akhirnya Tarokaja berangkat untuk membunuh Buaku, tetapi karena Buaku pandai bermain pedang, Tarokaja pikirnya pasti kalah oleh Buaku, daripada memalukan tuan karena gagal memukul Buakuyang pandai jurus pedang, Tarokaja memutuskan untuk menipu Buaku..."

Analisis:

Dari cuplikan di atas, terlihat bahwa Tarokaja membela Buaku, ini merupakan indeksikal dari adanya rasa kebersamaan antara masyarakat yang memiliki status sosial yang sama yakni golongan sosial bawah yang selalu dikondisikan oleh golongan sosial atas. Rasa kebersamaan inilah yang menjadi dasar untuk memperkokoh solidaritas antara sesama petani, tukang, pekerja, danpelayan untuk memberontak atau melawan golongan sosial atas yang diwujudkan dengan gerakan Gekokujo. Bagi golongan sosial bawah, perang yang berlanjut terus-menerus merupakan suatu penderitaan yang dirasakan setiap hari. A pabila serdadu datang menyerbu, pembakaran-pembakaran rumah atau gedung, pembunuhan, perbuatan keji, perampokan, terulang dimana-mana. Untuk taktik perang, mereka tanpa ragu-ragu membakar kampung-kampung dan hasil panen dari ladang dan sawah. Karena hal ini, golongan sosial bawah, seperti para petani, hidupnya menjadi menderita. Di dalam gejolak sosial seperti ini, timbul kesadaran dari para petani desa untuk mempertahankan kampungnya secara berasama-sama dari serangan atau ulah para penguasa. Akhirnya rasa kebersamaan sesama petani atau tukang dan sebagainya ini menjadi dasar yang kuat untuk membentuk sistem serikat kampung dan pertahanan kampung, sehingga para petani secara bersamasama mengurus jalan, irigasi air, dan tanah milik bersama orang-orang desa bahkan melawan para penguasa yang datang menyerang. Jadi, cuplikan yang menunjukkan adanya pembelaan Tarokaja terhadap Buakuyang samasama orang bawah merupakan suatu hal yang wajar dan sekaligus merupakan manifestasi bahwa dalam usaha untuk mewujudkan Gekokujo diperlukan suatu rasa kebersamaan dan persatuan untuk mempertahankan kampungnya, sehingga masyarakat bawah bisa hidup aman, tentram, dan sejahtera. Kemudian dari cuplikan di atas, Tarokaja berangkat untuk membunuh Buaku atas perintah tuannya merupakan indeksikal dari kesetiaan Tarokaja terhadap tuannya. Kesetiaan merupakan hal yang sangat diutamakan dalam hubungan tuan dan pembantu dalam masyarakat feodal Jepang, sehingga seandainya ada hamba atau pelayan (bawahan) melalaikan kesetiaan maka akan mendapat hukuman dari tuannya secara kejam.

\section{Cuplikan 3:}

"... Soko de ike ni hairi, kawauo o ou Buaku no geki o tsuite utoshita Tarokaja moO shimondo no sue no shuushouna Buaku no sugata o mite kesshin mo niburi, "sasemajiW a miyazu kaeja...sasemaji wa miyazu kaeja.. "nagekinagara, toubousasete shimaimasu.."

Terjemahan:

“...Buaku turun ke kolam yang ada, Tarokaja walaupun bermaksud membunuh dengan mengambil kesempatan Buaku yang dalam keadaan mengejar ikan, tetapi Tarokaja tidak tega membunuh melihat sosok dan sikap Buaku yang patut dihargai, akhirnya Tarokaja menyuruh melarikan diri kepada Buaku sambil berkata kerja orang bawah adalah melawan, kerja orang bawah adalah melawan..."

Dari cuplikan di atas, pertama, Tarokaja tidak tega membunuh Buaku. Ini menunjukkan adanya rasa kesetiakawanan antara Tarokaja dan Buakuyang sama-sama dari golongan sosial bawah dan tidak boleh saling membunuh. $\mathrm{Hal}$ ini merupakan indeksikal dari rasa kebersamaan golongan bawah yang mengabdi kepada tuan. Kedua, terlihat bahwa Tarokaja menyuruh Buaku melarikan diri sambil berkata kerja 
orang bawah adalah melawan menunjukkan bahwa Tarokaja menginginkan Buaku selamat hidupnya dari kekejaman tuannya dan memiliki pemikiran bahwa sebagai orang bawah harus melawan terhadap tindakan tuannya yang kejam dan semena-mena. Dengan demikian, cuplikan di atas merupakan indeksikal dari bangkitnya golongan sosial bawah dan kesadaran akan perlunya kebersamaan antara golongannya untuk melawan terhadap atasan atau tuan. Khusus pada kata-kata "kerja orang bawah adalah melawan" secara jelas menunjukkan bahwa cerita Buaku ini mereflesikan Gekokujo yang memang peristiwanya tejadi pada zaman M uromachi. Sebagai bukti bisa dilihat pada tahun 1334 terjadi gerakan pengusiran oleh para petani dan tukang kuli terhadap Waki Bukuro, seorang penguasa daerah dari pemerintahan kuil, karena Waki Bukuro dianggap sebagai pemimpin yang kejam dan tidak berperikemanusiaan. Kemudian terjadi pemberontakan para petani Harima (nama daerah) melawan tentara Shugo Daimyo A kamatsushi dan juga pemberontakan yang menuntut pembebasan pajak tahunan pada kuil Todaiji di Yamato, Kofukuji dan Iain-Iain mendobrak masuk ke daerah $\mathrm{N}$ ara. Pemberontakan-pemberontakan seperti ini sering terjadi di setiap daerah pada zaman M uromachi. Secara keseluruhan cuplikan di atas merupakan suatu bentuk sindiran terhadap penguasa dan sekaligus sebagai kritik sosial.

\section{Cuplikan 4:}

“...H ajime no uchiusukimi waruku omotteita nanushi mo, shidai ni koukishin o mukidashi ni teshi jigoku ya goraku no yousu o kikidashimasu ga, yurei Buaku mo shidai ni choushi no nami ni notte, ano you de nushi no oyajisama ga fujiyu nasatteiru kara to nushi mochimono o tsugitsugi ni toriageta ue, kono you no yashiki wa semakute shumimikuikarou kara, ano yolu no hiroi yashiki ni annai suru you meijirareta to itte, hisshi ni jitaishite yurushi o koinagara nageteiku nushi ato 0 , Buaku ga shitsuyou ni ottekimasu..."
Terjemahan:

“...Pertama tuan juga takut, tapi lambat laun mengungkapkan keingintahuan dan menanyakan keadaan surga dan neraka kepada hantu Buaku, hantu Buakupun seolah-olah semakin semangat menipu tuan, ayah tuan di alam akhirat hidupnya susah dan angkutlah barang-barang milik tuan satu persatu kesana, kemudian karena rumah tuan di dunia ini sempit dan susah ditempati, saya disuruh ayah tuan supaya menunjukkan rumah dan pekarangan yang luas di dunia akhirat, tuan menolak mati-matian dan lari sambil minta maaf, kemudian Buaku dibelakang tuannya terus mengejar tak mau kalah mengejar tuannya..."

\section{Analisis:}

Dari cuplikan di atas, pertama terlihat bahwa Buaku yang pura-pura jadi hantu yang semakin semangat menipu tuannya dengan mengatakan “...ayah tuan di alam akhirat hidupnya susah dan angkutlah barang-barang milik tuan satu persatu kesana..." Ini merupakan sindiran terhadap para penguasa yang hidupnya serba ada yang tak pernah merasakan bagaimana hidup menderita seperti yang dirasakan golongan sosial bawah. Kedua, perbuatan seorang Buaku sebagai pekerja yang menipu tuannya merupakan indeksikal dari sautu bentuk Gekokujo. Ketiga,Buaku mengatakan “...karena rumah tuan di dunia ini sempit dan susah ditempati, saya disuruh ayah tuan supaya menunjukkan rumah dan pekarangan yang luas di dunia akhirat.." yang menunjukan adanya sindiran atau kritikan terhadap tuan (penguasa) dan juga merupakan kecerdikan golongan sosial bawah untuk menipu golongan sosial atas dengan tujuan agar para penguasa pada zaman M uromachi ini sadar akan ketamakan, kekejaman, dan tindakan sewenangwenang yang mereka lakukan dalam kehidupan sehari-harinya. Keempat, dalam cuplikan di atas, terlihat bahwa si tuan berpikir jika melihat dunia akhirat dirinya harus mati terlebih 
dulu, sehingga tuan menolak mati-matian dan lari sambil meminta maaf. Ini menunjukkan adanya kesadaran dari penguasa (tuan) dan sekaligusmerupakan indeksikal dari kemenangan golongan sosial bawah dalam melawan golongan sosial atas. Kelima, Buaku dibelakang tuannya terus mengejar tak mau kalahyang merupakan refleksi dari suatu gerakan Gekokujo. Penampilan tokoh Buaku mengejar-ngejar tuannya dari belakang merupakan pemutar balikan karakter yang sengaja dibuat si pengarang untuk tujuan kritik sosial dan membuat gelak tawa para penonton sehingga cerita Buaku dalam drama Kyougen ini dapat dikatakan juga sebagai hiburan. Kondisi sosial seperti yang diungkapkan pada cuplikan 1 sampai cuplikan 4 di atas, memang pada zaman M uromachi terjadi dimana-mana di Jepang, sehingga kondisi sosial ssssseperti ini oleh para sastrawan kala itu dijadikan sumber inspirasi dalam menuangkan gagasannya kedalam karya sastra apapun genrenya.

Berdasarkan analisis tema, tokoh cerita, motivasi dan soiologis cerita Buaku di atas, pembahasannya seperti berikut :

Mengacu kepada pendapat Teun Van Djik, dalam analsis wacana kritis untuk melihat suatu teks dapat dilihat berdasarkan struktur makro, yaitu makna global dari suatu teks yang diamati dari topik/ tema yang diangkat oleh suatu teks. Dan struktur mikro, yaitu makna lokal dari suatu teks yang dapat diamati dari pilihan kata, kalimat dan gaya bahasa yang dipakai oleh suatu teks. Kemudian untuk me ngamatinya menggunakan metode hermeneutik. Menurut Ricoeur hermeneutika adalah proses penguraian yang beranjak dari isi dan makna yang nampak ke arah makna yang terpendam dan tersembunyi. Oleh karena itu, teks cerita Buaku diamati tema, kata, kalimat yang maknanya terpendam dan tersembunyi dengan cara menafsirkannya untuk menggambarkan konflik sosial yang terjadi antara masyarakat bawah (direpresentasikan oleh tokoh Buaku dan Tarokaja) dengan masya- rakat atas (direpresentasikan oleh tokoh tuan/ majikan).

Dilihat dari temanya, cerita Buaku secara sosiologis jelas mengangkat kondisi sosial politik yang terjadi pada zaman Muromachi. Kondisi sosial dan politik pada zaman Muromachi dilihat dalam kontek sejarahnya sangat memprihatinkan. Penguasa daerah pada zaman ini satu sama lain saling bertikai memperebutkan batas wilayah yang berpengaruh terhadap kehidupan rakyat. Selain itu para penguasa daerah (Shugo Daimyo) dalam menjalankan tugasnya bertindak tidak adil bahkan tidak berperikemanusiaan. Oleh sebab itu, kondisi sosial politik seperti ini mengakibatkan kehidupan rakyat menjadi menderita. Melihat situasi seperti ini, sastrawan Zeami peka dan memperhatikan apa yang terjadi di sekelilingnya. Melalui pengamatannya terhadap kehidupan masyarakat, Zeami menemukan hal yang menyebabkan keprihatinannya, Zeami berhasrat untuk menyampaikan keprihatinannya dan memikirkan cara-cara pemecahannya. Salah satu caranya melalui pertunjukan drama Kyougen dengan judul Buaku yang temanya telah dipaparkan di atas.

Dilihat dari tokoh ceritera, pemeran utama Buaku sebagai representasi dari masyarakat bawah yang harus mengabdi terhadap tuan/ majikan, Pada zaman Muromachi pengabdian seorang bawahan terhadap atasan sesuatu yang mutlak harus dilakukan. Maka jika bawahan membangkang atau mengabaikan pe ngabdiannya akan mendapat perlakuan yang kejam dari atasannya. Pembangkangan yang dilakukan oleh tokoh Buaku terlihat dari tindakan Buaku yang malas dan tidak setia lagi pada majikannya. Ketidaksetiaan dan perbuatan malas yang dilakukan tokoh Buaku seperti ini penulis menafsirkannya sebagai suatu bentuk perlawanan dari masyarakat bawah terhadap tuan atau penguasa dan sekaligus merupakan suatu bentuk kritikan terhadap perilaku para penguasa pada zaman Muromachi. 
Dilihat dari motivasi ceritanya, di dalam cerita Buaku motivasi adalah masyarakat bawah pada zaman Muromachi mendapat perlakuan yang tidak adil dan tindakan yang tidak berperikemanusiaan dari masyarakat atas atau penguasa. Semua perkataan dan perbuatan tokoh cerita baik tokoh utama (major) dan tokoh pembantu(minor) dalam kisah tersebut berangkat dari motivasi ini. Motivasi ditunjukkan dengan kata "...tuan tak tahan menahan kesabarannya terhadap ketidaksetiaan atau kemalasan Buaku, menyuruh Tarokaja supaya membunuh Buaku..." Pada kalimat tersebut menurut penulis mengandung makna bahwa si tuan bertindak secara tidak berperikemanusiaan yaitu tega membunuh pekerjanya dan merupakan pencerminan dari kekejaman seorang majikan. Berdasarkan wacana kritis kalimat tersebut merupakan sindiran terhadap penguasa yang kejam. Pada kal imat “...ayah tuan di alam akhirat hidupnya susah dan angkutlah barang-barang milik tuan satu perstu kesana... "kalimat ini menunjukkan adanya sindiran terhadap ketidak adilan penguasa zaman Muromachi yang hidup kaya raya tidak memperdulikan kehidupan rakyat yang menderita, sehingga menimbulkan anti pati dari rakyat terhadap penguasa dan akhirnya muncul gerakan Gekokujo.

Dilihat dari anal isis sosi ol ogis cerita Buaku, Zeami sebagai penulis naskah Buaku mengangkat kondisi sosial dan politik pada zaman Muromachi yang ia lihat sangat memprihatinkan. Sehingga dengan talenta kesastrawannya, ia ingin menyampaikan rasa keprihatinannya melihat kehidupan masyarakat bawah yang menderita akibat ulah dari penguasa melalui pertunjukkan drama Kyougen dengan judul Buaku. Dalam cerita Buaku Zeami mengungkapkan tentang Gekokujo yaitu perlawanan dari masyarakat bawah (petani, tukang, buruh) yang menderita terhadap masyarakat atas (penguasa) yang terjadi pada zaman Muromachi. Sebagai manifestasi perlawanan yang dilakukan oleh masyarakat bawah ini, dapat ditunjukkan melalui penafsiran kata, kalimat kalimat yang terkandung pada teks cerita Buaku. Zeami melalui kata atau kalimat dalam teks cerita Buaku mencoba untuk mengkritisi pihak penguasa (D aimyo dan Daikan) yang bertindak sewenang wenang terhadap masyarakat bawah. Kemudian, me Ialui tokoh cerita Buaku, Tarokaja dan tuan/ majikan terselubung dialog-dialog yang mengindeksikalkan adanya pertentangan atau perlawanan masyarakat bawah (Buaku dan Tarokaja) dengan masyarakat atas (tuan. majikan). Hal ini dapat dilihat dari kalimat “...tuan tak tahan menahan kesabarannya terhadap ketidaksetiaan dan kemalasan Buaku..." makna dari keti daksetiaan dan kemalasan yang dilakukan Buaku merupakan suatu perbuatan melawan terhadap majikan, dan juga merupakan suatu sindiran terhadap kondisi sosial dan politik pada zaman Muromachi serta merupakan indeksikal dari perlawanan masyarakat bawah.. Kemudian pada kalimat “...Tarokaja tidak tega membunuh Buaku melihat sosok yang patut dihargai. Akhirnya Tarokaja menyuruh melarikan diri kepada Buaku sambil berkata "kerja orang bawah adalah melawan... kerja orang bawah adalah melawan..." makna dari kalimat "kerja orang bawah adalah melawan... kerja orang bawah adalah melawan.." yang diucapkan oleh Tarokaja merupakan perlawanan dari seorang pekerja terhadap majikan sekaligus merupakan sindiran terhadap penguasa pada zaman muromachi. Pada kalimat “...Buakupun seolah-olah semakin semangat menipu tuan, ayah tuan dialam akhirat hidupnya susah dan angkutlah barang-barang milik tuan satu persatu kesana..., saya disuruh ayah tuan supaya menunjukkan rumah dan pekarangan yang luas di dunia akhirat, tuan menolak mati-matian dan lari sambil minta maaf, kemudian Buaku dibelakang tuannya terus mengejar tak mau kalah..." makna dari kalimat Buaku semakin semangat menipu tuan merupakan kecerdikan dari masyarakat bawah yang tidak boleh 
dianggap sepele, yang memang pada zaman Muromachi rakyat sudah mulai memiliki pemikiran maju, sehingga masyarakat bawah pada zaman ini sudah dapat memikirkan perlunya persatuan, kebersamaan dan berpikir kritis. A kibatnya masyarakat bawah sudah bisa menentang kebijakan yang dilakukan pihak penguasa (D aimyo). Seperti yang ditunjukkan pada cerita Buaku bahwa berkat kecerdikannya si Buaku bisa menipu tuannya sehingga tuannya terpedaya tipuan Buaku. Buaku menipu tuan/ majikan merupakan indeksikal dari perlawanan bawahan terhadap majikannya dan sekaligus merupakan refleksi dari Gekokujo. Kemudian kalimat " ...tuan menolak matimatian dan Iari sambil minta maaf, Buaku mengejar tuannya dari belakang tak mau kalah... " makna dari kalimat Buaku mengejar tuan adalah bawahan (pekerja) secara etika tidak sopan telah berani mengejar majikan untuk mengikuti perintahnya seolah-olah dirinya yang lebih berkuasa. $\mathrm{Hal}$ ini merupakan refleksi dari Gekokujo yang memang pada zaman Muromachi ini terjadi dimana-mana.

Berdasarkan pendekatan sosiologis yang bertolak dari asumsi bahwa sastra merupakan pencerminan kehidupan masyarakat. Melalui karya satra seorang pengarang mengungkapkan problem kehidupan yang pengarang sendiri berada di dalamnya. Pendekatan sosiologis dalam sejarah awal kemunculannya memandang sastra sebagai cermin sejarah, terutama sejarah pertentangan kelas. Cerita Buaku jelas mencerminkan kehidupan masyarakat pada zaman Muromachi yang penuh gejolak sosial dan politik yang mengakibatkan masyarakat bawah menderita. Gejolak sosial dan politik yang terjadi ditunjukkan dengan adanya tindakan sewenang-wenang dan ketidakadilan yang dilakukan pihak penguasa terhadap masyarakat bawah, yang mengakibatkan hidup masyarakat bawah tertekan dan menderita. A kibatnya timbul reaksi dari masyarakat bawah untuk melawan penguasa pada zaman Muromachi dengan berbagai cara, Akhirnya semangat melawan terhadap penguasa ini meluas menjadi suatu gerakan yang dinamakan Gekokujo, yang esensinya adalah rakyat bangkit, berpikir kritis, bersatu, dan menciptakan rasa kebersamaan diantara masyarakat bawah khususnya petani desa untuk melawan para penguasa yang memperlakukan masyarakat bawah secara tidak manusiawi. Zeami ketika melihat fenomena Gekokujo dalam kehidupan sehari-hari pada zaman Muromachi, sangat terpanggil nalurinya untuk mengangkat Gekokujo ini. Dan akhirnya Zeami sebagai sastrawan drama mencoba membuat naskah Kyougen berjudul Buaku dengan seting cerita fenomena Gekokujo. Dan setelah dianalisis dan dibahas cerita Buaku ini sarat merefleksikan Gekokujo yang terjadi pada zaman M uromachi dan sekaligus merupakan kritik sosial.

\section{PENUTUP}

Cerita Buaku dalam drama Kyougen merupakan cerita yang sangat kaya dengan peristiwa yang terjadi pada zaman M uromachi, kira-kira tahun 1333 hingga tahun 1573. Realitas sosial dan politik pada zaman M uromachi yang terkandung dalam cerita Buaku secara sosiologis merupakan cermin kondisi zaman yang bersangkutan. Zaman M uromachi pada dasarnya suatu zaman yang paling banyak terjadi huru-hara atau pertikaian atau pemberontakan yang sifatnya meluas ke seluruh provinsi. Pemberontakan-pemberontakan yang terjadi pada zaman M uromachi ini diantaranya adalah pemberontakan $\mathrm{N}$ anbokucho (pertikaian kekaisaran utara dan selatan) tahun 13361392, pemberontakan 0 nin tahun 1467-1447, dan pemberontakan Gekokujo (1573-1600). Masa yang kacau secara sosial dan politik ini berlangsung lebih dari seratustahun. Kemudian masa yang kacau ini dijadikan kesempatan oleh para penguasa provinsi (Shugo Daimyo) untuk memperluas daerahnya. Akhirnya para Shugo Daimyo ini semakin kuat dan memiliki tanah yang luas. Dengan kekuatan dan kekuasaan yang mereka miliki, para penguasa men- 
jalankan tugasnya dengan cara yang kejam dan tidak mempedulikan masyarakat yang dikuasainya. A kibat dari tindakan penguasa seperti itu, kehidupan golongan sosial bawah menjadi semakin menderita baik secara lahiriah maupun batiniah. Akhirnya timbul kesadaran dari golongan sosial bawah untuk bangkit dari penderitaan, timbul rasa antipati terhadap para penguasa yang kejam dan bertindak sewenang-wenang. Masyarakat bawah, khususnya para petani, sadar akan perlunya persatuan dan kebersamaan antar sesama golongan sosial bawah untuk melawan penguasa tersebut. Para petani akhirnya dapat membentuk perserikatan kampung yang dikenal dengan istilah Gosonrengo. Kemudian para petani dan masyarakat bawah lainnya yang merasa antipati dari beberapa kampung bersatu, kemudian memukul mundur kekuatan pasukan penguasa yang datang menyerang, menentang para panguasa yang kurang disenangi termasuk penguasa pemerintahan kuil (D aikan). Kondisi seperti ini selanjutnya meluas menjadi suatu gerakan bawahan melawan atasan yang dikenal dengan istilah Gekokujo. Zeami, sebagai penulis naskah, ketika itu melihat dan mengalami realitas sosial dan politik pada zaman M uromachi seperti yang dijelaskan di atas, juga turut merasakan kesedihan masyarakat bawah akibat dari ulah para penguasa yang bertindak sewenang-wenang, menyiksa bahkan memaksa petani dan tukang kuli untuk berbuat demi kepentingan penguasa. Realitas sosial yang terjadi, seperti gejolak sosial, konflik sosial, atau pertentangan sosial antara golongan sosial bawah (petani, tukang, pekerja, dan pelayan) dengan golongan sosial atas (penguasa, tuan, atau majikan) pada zaman $\mathrm{M}$ uromachi, dijadikan sebagai latar cerita Kyougen, salah satunya berjudul Buaku. Berdasarkan analisis cerita Buaku melalui pendekatan sosiologis, dapat disimpulkan bahwa cerita Buaku padadasarnya merefleksikan Gekokujo yang terjadi pada zaman M uromachi, yakni sebuah gerakan perlawanan yang dilakukan oleh golongan sosial bawah yangdirepresentasikan oleh tokoh Buaku dan Tarokaja terhadap golongan sosial atas yang direpresentasikan oleh tokoh tuan/ majikan. Selain itu, cerita Buaku ini juga merupakan cerita yang mengadung sindiran atau kritik sosial terhadap para penguasa (Shugo D aimyo dan D aikan) yang hidupnya serba ada, tamak, kejam, dan bertindak sewenang-wenang terhadap petani dan tukang pada zaman M uromachi. Dari ceritera Buaku ini, tentu kita harap dapat mengambil hikmahnya bahwa "hanya dengan rasa kebersamaan dan persatuan kita dapat kokoh dan kuat dalam melawan suatu ketidakadilan, keserakahan, kezaliman serta kesewenang-wenangan dimanapun terjadi". Melihat dari bagaimana masyarakat Jepang pada zaman M uromachi melakukan kritik sosial terhadap para penguasa melalui sebuah pertunjukkan drama, maka sebaiknya kita pun dalam melakukan kritikan terhadap penuasa melalui drama akan terasa lebih luwes dan tidak destrukltif Kajian terhadap cerita Buaku ini menurut penulis ada relevansinya dengan situasi bangsa kita yang sedang membangun demokratisasi dan reformasi, khususnya dalam kebebasan menyampaikan pendapatdi muka umum dalam rangka mengkritisi pihak penguasa. Kritikan terhadap penguasa yang zalim, tamak dan tidak memperdulikan rakyat sebaiknya melalui teks yang disampaikan dengan pertunjukkan drama terasa lebih luwes dan tidak destruktif.

\section{DAFTAR PUSTAKA}

Asoo, Isoji. 1983. Sejarah Kesusastraan Jepang. Jakarta: UI Press.

Inoura, Yoshinobu. 1971. The Traditional Theater of Japanese. Tokyo: Iwanami Shoten.

Kiyoshi, Yokoi. 1993. N ihonshi Gaisetsu. Tokyo: Tokyo Daigaku.

Matsuda, Tamotsu. 1976. N oh Kyougen no N yumon. Tokyo: Bunken.

Martin, Roderick. 1990. Sosiologi Kekuasaan (penerjemah: Herry Joediono). Jakarta: Rajawali 
Maqdum, Mufatis. 2011. A nalisis wacana vs analisis wacana kritis plus. http;// mutafismaqdum.w ordpress.com/2011/03/29/ analisis-wacana-vs-analisis wacana kritis plus/2011 dilihat pada 01 Desember 2017.

Mega, Nuridha. 2013. Teori hermeneutika. http:/ /nrdha.wordpress.com/2013/10/01/ teorihermeneutika dilihat pada 02 Desember 2017.

N azir, Mohammad. 1999. M etode Penelitian. Jakarta: Ghalia Indonesia.

Piliang, Dasril. 2017. Pertentangan Laki-Laki M inangkabau Terhadap Budaya M inangkabau dalam Novel Hamka. Jurnal Kebahasaan dan Kesastraan Genta Bahtera Vol. 3 (1) : 1-11. Riau : Kantor Bahasa Kepulauan Riau.
Sakamoto, Taro. 1982. Jepang Dulu dan Sekarang. Jogjakarta: Gadjah Mada University Press.

Semi, A tar. 1993. M etode Penelitian Sastra. Bandung: Angkasa.

Sumardjo, Jakob. Saini K.M. 1994. A presiasi Kesusastraan. Jakarta: Gramedia Pusrtaka Utama.

Satari, Endah. 2003. N ilai M oral Perkawinan yang Tercermin dalam D rama "Toki no $\mathrm{U}$ ji Gami "karya Kikuchi Kan. Jurnal Sastra Jepang 2 (2) : 58-72. Bandung: Program Studi Sastra Jepang Fakultas Sastra Universitas Kristen Maranatha Bandung. 